\title{
Viewpoint
}

\section{The LIP role in research and development projects in the library and information field}

\author{
IAN MALLEY (Coordinator) \\ Library and Information Plan for Leicestershire
}

\section{Introduction}

One of the proposed functions for the new Library and Information Commission suggested in the consultation paper on the proposed new body, distributed by the Department of National Heritage, is:

to develop, in association with the relevant Government Departments as far as necessary to achieve consonance with Government policy, a strategy for research and development requirements in the library and information field, having regard to the needs and interests of all areas of library and information activity and of all parts of the UK, and to secure the disbursement of the available funds in accordance with that strategy. ${ }^{(1)}$

If the Commission manages to assume this strategic role and is able to shape and direct research and development in the library field - wherever it is funded and not just that which is currently funded by the British Library Research and Development Department - then it will be major achievement. It will not be easy, however, given that it may involve the ceding of an important area of policy by a number of powerful departments of state, including the Department of Trade and Industry, Environment and Health, all of whom direct very substantial resources towards information services (in the widest sense). If an overall strategy can be agreed at all then it will be on the basis of cooperation and partnership, and part of the package of an agreed strategy is likely to be cooperation and partnership both in funding research and in delivering research. In other words we can expect to see more joint funding of research (as the BLRDD and OAL did) and we can expect an increasing partnership requirement in executing research (as in the PLDIS and EC grants).

The proposed Library and Information Commission, as in all areas within its purview, will rely on other agencies to deliver within the framework of the national research strategy it constructs. In preparing this strategy, however, and particularly in ensuring the delivery of this research, it would be unwise for the Commission to ignore strategic planning agencies at the local and regional level with research interests. This paper takes just one of these agencies - LIPs - and examines their role, performance and potential in delivering research within a culture of cooperation and partnership. This analysis is derived largely from information in the recent Survey of Library and Information Plans. ${ }^{(2)}$ 


\section{Externally funded LIP research}

Table 1 identifies externally funded LIP research. The research projects exclude all projects to prepare and establish LIPs themselves.

\section{Table 1}

\section{Research \\ 1. Pilot trial of NERIS (National Educational Resources Information Service) database in public libraries \\ 2. The European Business Information Centre: a proposal to develop a 1992 Single Market Club as a joint venture involving Gloucestershire County Council and other local government and business sector partners}

3. A Business Information Service for the M3/M4 Blackwater Valley Area

4. PANDA (Public Access to a Newspaper Database and Archive) Project

5. Cooperative training, open learning and public library staffs
6. Reassessing the operations and role of the Provincial Joint Fiction Reserve review

\section{LIP}

Beds \& Bucks Information (BBI)

Gloucestershire and Hereford \& Worcester LIP (LIP involved as facilitator)

HATRICS - the Southern Information Network

Information North Information North (LIP involved as funding partner)

\section{Partners}

NERIS, Bedfordshire

Public Libraries, Buckinghamshire Public

Libraries

Gloucestershire County Council,

Hereford and

Worcester County

Council,

Gloucestershire

Chamber of

Commerce,

Gloucestershire

Training and

Enterprise Council

Hampshire County

Libraries, Berkshire

County Libraries,

Surrey County

Libraries

Northern Echo, Information North

Northern Training Group (comprising 10 local library authorities), Information North, Training and Enterprise Councils of Durham, North Yorkshire and Wearside, Local Government Management Training Board, Scottish Council for Educational Technology

Information North (LIP involved as project manager)
Circle of Officers of National \& Regional Library Systems (CONARLS), Information North
PLDIS,

$£ 35,400$

Gloucestershire

County Council,

Hereford and

Worcester County

Council,

Gloucestershire

Chamber of

Commerce,

Gloucestershire

Training and

Enterprise Council

$£ 46,300$

PLDIS, Hampshire

County Libraries, Berkshire County Libraries, Surrey County Libraries

PLDIS, Northern Training Group, Information North, Training and Enterprise Councils of Durham, North Yorkshire and Wearside, Local Government Management Training Board

BLRDD, Library and Information Co$£ 37,780$ operation Council 
7. Feasibility study for the establishment of a National Central Reserve for Children's Fiction

8. The information needs of Library and ethnic minority organizations: an investigation into issues identified by the Library and Information Plan for Leicestershire

9. Information technology support and advice project for voluntary and ethnic minority groups feasibility study

10.Information technology support and advice service for voluntary and ethnic community groups
Information North (LIP involved as project manager)

Information Plan for Leicestershire (Project managed on behalf of the LIP)

Library and Information Plan for Leicestershire (Project managed on behalf of the LIP)

Library and Information Plan for Leicestershire (Project managed on behalf of the LIP)
11.Mapping the links between information and advice centres in rural Leicestershire

\section{Cooperative arrangements \\ for the management of
stock in languages other \\ for the management of
stock in languages other than English}

\section{Public understanding of science}

\section{Policy making and strategic management: a course for managers of library and information services}

Library and Information Plan for Leicestershire (LIP involved as part of the research team)

\section{Library and}

Information Plan for Leicestershire (LIP involved as part of the research team)

\section{Library and}

Information Plan for Leicestershire (LIP involved in funding application)

Library and Information Plan for Leicestershire (LIP involved as part of the research team)
Circle of Officers of

BLRDD

National \& Regional

Library Systems (CONARLS), Information North

Leicestershire Libraries

BLRDD

$£ 2,000$

and Information

Service, Capital

Planning

Information

Leicestershire Libraries and Information Service, Leicester Polytechnic, Loughborough University of Technology DLIS

Leicestershire Libraries and Information

Service, Leicester

Polytechnic, Loughborough University of Technology DLIS

Leicestershire Libraries and Information Service, Library and Information Plan for Leicestershire

Leicestershire Libraries and Information Service, Library and Information Plan for Leicestershire, Loughborough University of Technology DLIS

Leicestershire Libraries and Information

Royal Society

Service, Loughborough University of Technology DLIS

Loughborough

University of

PLDIS Leicester-

shire County

Council, Leicester

Polytechnic,

Loughborough

University of

Technology

PLDIS, City Action $£ 36,000$

Team, Leicestershire County Council, Leicester Polytechnic, Loughborough University of Technology

BLRDD

Library and

nformation

Cooperation Council

Technology DLIS, University of Leicester Library, Leicester Polytechnic Library, Capital Planning Information Ltd., Maurice Line
BLRDD 
Although it is unwise to draw too many conclusions from such a small number of projects, several observations may be made.

Firstly, although the number of externally funded research and development projects is a respectable fourteen, only five LIPs have been involved in such projects, and two LIPs alone have accounted for twelve of the fourteen projects. This unevenness does not necessarily mean that LIPS are generally indifferent to research involvement - this table excludes project applications which have failed or which have had to be abandoned. At least two other LIP-engineered research projects have failed through lack of partnership finance.

Secondly, the nature of LIP involvement with the projects has been quite varied, as the table shows. However, one might broadly describe the LIP role in most cases as one of facilitator or broker. In other words the degree of the LIP involvement in the day-to-day work of the project is limited for the most part. Such an enabling role is very much within the spirit of the LIP concept.

Thirdly, the two key research and development funders are BLRDD and PLDIS. There is a marked difference in the amount of funding provided by the BLRDD (relatively low) and that given under the PLDIS scheme (relatively high). This should not be translated as meaning BLRDD is a poorer or less important source of funding - many factors determine the level of funding available, not least that the level is based on need. Likewise the PLDIS, where it is important to note that the level of PLDIS funding is dependent in part on the level of local financial input to the projects.

Finally, the partners in most of the projects are from the library sector. Only three projects have involved partners from the commercial sector (two involving Chambers of Commerce and Training and Enterprise Councils, and one a newspaper).

This is indicative of the limited success that LIPs have had in involving the commercial sector, and it is a failure of, for example, PLDIS projects in general. If the shape of research funding for library and information matters is towards partnership with other sectors, then the prospects are not promising.

Would these projects have been proposed or won without LIP involvement? Such might-have-been questions are always unfair, and impossible to answer without a detailed knowledge of the circumstances. In several cases, however, there is no doubt that LIPs played a decisive ole in putting the partnership together

\section{LIP research (funded from within the LIP or within the LIP area)}

Table 2 identifies internally and locally funded LIP research. 
Table 2

\begin{tabular}{|c|c|c|c|c|}
\hline Research & LIP & Partners & Funder(s) & Funds \\
\hline $\begin{array}{l}\text { 1. Information services of } \\
\text { voluntary bodies, } \\
\text { including youth } \\
\text { information }\end{array}$ & $\begin{array}{l}\text { LIP Action (Northern } \\
\text { Ireland) }\end{array}$ & $\begin{array}{l}\text { Northern Ireland } \\
\text { Council for Voluntary } \\
\text { Action, Community } \\
\text { Development } \\
\text { Foundation, LIP } \\
\text { Action (Northern } \\
\text { Ireland) }\end{array}$ & & \\
\hline $\begin{array}{l}\text { 2. Survey of user needs in } \\
\text { business information by } \\
\text { the Business Information } \\
\text { Forum }\end{array}$ & $\begin{array}{l}\text { LIP Action (Northern } \\
\text { Ireland) (LIP involved } \\
\text { as funder) }\end{array}$ & $\begin{array}{l}\text { Business Information } \\
\text { Forum, LIP Action } \\
\text { (Northern Ireland) }\end{array}$ & $\begin{array}{l}\text { Business } \\
\text { Information Forum, } \\
\text { LIP Action } \\
\text { (Northern Ireland) }\end{array}$ & $£ 10,000$ \\
\hline $\begin{array}{l}\text { 3. Survey of GPs' } \\
\text { information needs in } \\
\text { Wandsworth, Merton } \\
\text { and Sutton in order to } \\
\text { develop the service at } \\
\text { St George's Library and } \\
\text { identify gaps in } \\
\text { information provision }\end{array}$ & SWIFT & $\begin{array}{l}\text { SWIFT, St George's } \\
\text { Library, Merton, Sutton } \\
\text { and Wandsworth FHSA }\end{array}$ & & \\
\hline $\begin{array}{l}\text { 4. Survey of information } \\
\text { needs of local businesses }\end{array}$ & SWIFT & & & \\
\hline $\begin{array}{l}\text { 5. Survey of health } \\
\text { information providers } \\
\text { computer hardware, } \\
\text { software and databases }\end{array}$ & SWIFT & & & \\
\hline
\end{tabular}

It would be easy (and it would be a mistake) to dismiss the LIP research projects which have not, for whatever reasons, benefitted from external funding. One cannot simply assume, for example, that the research did not merit external funding, but one should be able to assume that if the research was done it met a real need. The identification of 'internally funded' research and the assumption of necessity, is of considerable consequence to the Commission in its national research strategy aspirations. Firstly, the development of such a strategy must take into account all research in the library and information field, whether funded or not. Secondly, and possibly more importantly, the strategy must at least recognize the research that is carried out locally in response to real need - and unfunded LIP research is only one part of this.

One comment that should be made on Table 2 is that two projects (those involving LIP Action Northern Ireland) were funded in large part by the LIP concerned. Similarly in Table 1 one or two projects with which Information North was associated were the recipients of finance from the LIP itself. LIP-funded projects must be regarded as exceptional cases given the very limited resources of LIPs, but if any such resources can be accumulated within a LIP it could provide valuable cash to kick-start partnership projects which require a local funding contribution. 


\section{Conclusion}

The amount of research activity with which LIPs have been associated so far may not suggest that they are major players. Nevertheless the substantial research involvement of two LIPs in particular indicates that there is considerable potential for LIPs to take one or several different roles within research project partnerships. These various roles may be categorized as follows:

\section{LIP as initiator and facilitator}

The LIP identifies areas of local need, identifies potential partners, and identifies the necessary financial resources. In this respect the LIP is operating very much within the philosophy and objectives of the LIP concept. The LIP manager may retain some degree of involvement once the project begins as an adviser or an observer. Ideally the project could be described as being managed on behalf of the LIP.

\section{LIP as administrator or manager}

Irrespective of the LIP's earlier involvement in identifying need, partners, and resources, the LIP through its manager is managing the project, although not necessarily on a full time basis. The LIP in this case may be managing the project on behalf of another organization. This role can be demanding in terms of time, and does not make best use of LIP managerial resources.

\section{LIP as active partner}

The managerial role of the LIP develops into a fully developed research input into the project. The demands in time are great and this will substantially limit the LIP's ability to pursue other projects and other areas of activity.

\section{LIP as 'sole trader'}

The LIP acts independently and without partners, and the work of the project may or not be executed by the LIP manager. In this role the LIP is operating entirely outside the LIP concept, and effectively is acting in competition with other local organizations. The LIP thereby loses the ability to act as an honest broker and to be recognized as having a strategic role.

In practice the boundaries between the above roles are often blurred, and moreover a LIP's role may vary from one project to another. This lack of clarity can lead to uncertainty over the role of LIPs in research and development projects in prospective local partnerships. This can in turn prevent the LIP taking on any research and development role beyond just observing rather than influencing project development in the area. Most importantly this will have implications for other LIP activity - other cooperative initiatives, information dissemination, strategic planning in general, etc.

The varied role of LIPs thus has implications for the wider strategic role of a LIP in its own geographical area. However, it is the wider strategic, collective research and development role of LIPs which also needs to be considered, especially in the context of the future direction of UK research as envisaged by the Department of National Heritage consultation paper. If the trend is towards greater partnership in research and development on library and information matters, and if the proposed Library and Information Commission is successful in its aspirations to take the 
strategic, national role, then there surely must be a contributory role - at a local, regional and even national level - for LIPs which have both strategic and cooperative responsibilities.

An illustration of the potential strategic role of LIPs is to be found in the recent paper by LIPLINC in the particular context of PLDIS ${ }^{(3)}$. Table 1 illustrates only moderate success by LIPs in securing partnership funding through PLDIS, even though from the outset the Minister for the Arts recognized the value of 'projects arising from Library and Information Plans'. Unfortunately the limited involvement of LIPs so far in PLDIS projects does not help the argument for LIPs to provide a local conduit for future PLDIS projects, as proposed in the LIPLINC paper. Nevertheless the case still has some validity.

The report on PLDIS to the PLDIS Advisory Committee in March 1993 noted some of the outcomes of PLDIS, which have:

encouraged many local authorities, cooperatives and voluntary organizations to bring forward new initiatives and to seek out partners in both the public and private sectors to carry through a wide range of projects;

brought into projects national and other money which might not otherwise have been acceptable locally as PLDIS funding has added credibility to projects;

given a limited number of library authorities useful experience in working with partners, creating business plans and managing sometimes complex projects to successful conclusions. ${ }^{(4)}$

In many ways these are the outcomes which are the objectives and modus operandi of many LIPs, inside as well as outside research and development projects, and illustrate how LIPs can partly achieve their objectives through project involvement. Such an assessment of a LIP as the above would be welcome to the ears of most LIP managers.

The PLDIS report estimates that the level of PLDIS funding available 'has tended towards small scale local projects which have had minimal strategic impact'. ${ }^{(3)}$ This is probably true of all research and development funding in the library and information field, and virtually inevitable in projects which are developmental and have to reflect local need and justify local input of financial resources. But the important point here is the conclusion that this strategic dimension has been missing. Again the door is open for the strategic capabilities of LIPs.

The challenge for any future PLDIS funding is to bridge this local/national gap and to enable PLDIS funding to fit into the wider strategy of research and development on library and information issues. Several parts of the assessment of PLDIS funding above reinforce the need for agencies with the responsibilities that LIPs claim.

It is unfortunate, incidentally, that as a consequence of the Minister's specific responsibilities for public libraries in England being undertaken by a new, separate, dedicated group with no formal link to the Commission, it will be this advisory group which will take over the task of advising the Department on its direct awards to public library authorities (under the Public Library Development Incentive Scheme and any successor schemes). ${ }^{(1)}$ This immediately seems to undermine the ability of the Commission to exert a strong and effective strategic role in research and development, and in turn clouds the clear definition of national strategy which the proposed Commission would 
regard as necessary and to which it aspires.

Notwithstanding these problems at the centre, the potential role for individual local and regional LIPs is considerable. This role could be basically twofold:

1. The LIP would be the designated agency enabling and facilitating research and development partnerships at local and regional level.

2. The LIP would be the designated agency providing the interface between centrally-funded, national research funding and local sources of research and development funds (eg funds available within local government or from central government via local government).

If the library and information field has to become less dependent on central funding and more on local funding, then this particular role will be not only locally vital, but essential to the validity of a national strategic role envisaged for the Library and Information Commission.

\section{References}

1. Department of National Heritage. Proposed new Library and Information Commission: a consultation paper. London: Department of National Heritage, 1994.

2. Buckley, Barbara J. Survey of Library and Information Plans (British Library Project RDD/ CT/168). London: The British Library, 1993.

3. LIPLINC. Library and information plans at the crossroads: the case for their continued support. LIPLINC, 1993.

4. Huse, Roy. Public Library Development Incentive Scheme 1988-1992: a strategic evaluation. A report to the PLDIS Advisory Committee. London: PLDIS, 1993. 